\title{
Chronic obstructive pulmonary disease as an independent risk factor for cardiovascular morbidity
}

This article was published in the following Dove Press journal:

International Journal of COPD

3 September 2009

Number of times this article has been viewed

\author{
Joseph Finkelstein \\ Eunme Cha' \\ Steven M Scharf ${ }^{2}$ \\ 'Welch Center for Prevention, \\ Epidemiology and Clinical Research, \\ Johns Hopkins University, Baltimore, \\ MD, USA; ${ }^{2}$ Division of Pulmonary \\ and Critical Care Medicine at the \\ Department of Medicine, University \\ of Maryland School of Medicine, \\ Baltimore, MD, USA
}

Rationale: Recent studies described association between chronic obstructive pulmonary disease (COPD) and increased risk of cardiovascular diseases (CVD). In their analysis none of these studies accounted for sociodemographic factors, health behaviors, and patient comorbidities simultaneously.

Objective: To study whether COPD diagnosis is an independent risk factor for CVD.

Methods: Subjects aged 40 years and older $(\mathrm{N}=18,342)$ from the sample adult file of the 2002 National Health Interview Survey (NHIS) were included in the analysis. Chi-squared tests and odds ratios (OR) were utilized to compare the data. Multiple logistic regression was employed to analyze the association between COPD and CVD with simultaneous control for sociodemographic factors (age, gender, race, marital status, education, income), health behaviors (tobacco use, alcohol consumption, physical activity), and patient comorbidities (diabetes, hypertension, high cholesterol, and obesity). The analysis employed NHIS sampling weights to generate data representative of the entire US population.

Results: The COPD population had increased prevalence of CVD $(56.5 \%$ vs $25.6 \% ; P<0.0001)$. Adjusted logistic regression showed that COPD patients $(\mathrm{N}=958)$ were at higher risk of having coronary heart disease $(\mathrm{OR}=2.0,95 \% \mathrm{CI}: 1.5-2.5)$, angina $(\mathrm{OR}=2.1,95 \% \mathrm{CI}: 1.6-2.7)$, myocardial infarction $(\mathrm{OR}=2.2,95 \% \mathrm{CI}: 1.7-2.8)$, stroke $(\mathrm{OR}=1.5,95 \% \mathrm{CI}: 1.1-2.1)$, congestive heart failure $(\mathrm{OR}=3.9,95 \% \mathrm{CI}: 2.8-5.5)$, poor circulation in lower extremities $(\mathrm{OR}=2.5,95 \% \mathrm{CI}: 2.0-3.0)$, and arrhythmia (OR $=2.4,95 \% \mathrm{CI}: 2.0-2.8)$. Overall, the presence of COPD increased the odds of having CVD by a factor of 2.7 (95\% CI: 2.3-3.2).

Conclusions: These findings support the conclusion that COPD is an independent risk factor for CVD.

Keywords: chronic obstructive pulmonary disease, cardiovascular disease, risk factors, population-based analysis, case-control study

\section{Introduction}

Chronic obstructive pulmonary disease (COPD) is the fourth leading cause of death of adults in United States and it is projected to be the third leading cause of death by $2020 .^{1}$ Nonrespiratory diseases account for more than $50 \%$ of deaths in COPD patients. ${ }^{2}$ A number of previous studies demonstrated an association between COPD and cardiovascular disease. ${ }^{3-11}$ In fact, the presence of COPD may be an independent risk factor for the development of cardiovascular disease (CVD) above that associated with the most widespread factor these diseases have in common, namely smoking. ${ }^{5-9}$ Further, the Lung Health Study showed that age, smoking, male gender, married state, higher diastolic blood pressure, and poor pulmonary function were the strongest
Finkelstein Welch Center for Prevention, Epidemiology and Clinical Research, Johns Hopkins University, 2024 E Monument St, Rm. 2-615, Baltimore, MD 21205, USA Tel +l 4I05580480

Fax + I 4105580470

Email jfinkel9@jhmi.edu 
cardiovascular risk factors in COPD, while high baseline forced expiratory volume in one second $\left(\mathrm{FEV}_{1}\right)$, alcohol use, smoking cessation, and education were protective factors. ${ }^{12}$

Data consistent with the notion that COPD could be an independent risk for CVD come from the population-based studies $^{13,14}$ that showed that the lower the FEV , the higher the risk of CVD. However, many conditions, including heart failure and other lung diseases, can result in a reduced $\mathrm{FEV}_{1}$. Thus these studies are not specific for COPD. In a longitudinal health cohort study, Curkendall and colleagues showed that the diagnosis "COPD" increased the risk for hospitalization and deaths due to CVD. ${ }^{6}$ However, in this study, no simultaneous adjustment for sociodemographic and lifestyle risk factors for CVD, including physical activity, alcohol consumption, and smoking, was performed. Thus, while there are some indications that COPD may be a risk factor per se, to date only suggestive data have been presented. Further there are no US population based studies addressing the potential that COPD is a risk factor for CVD.

The notion that COPD itself is an independent risk for CVD has potentially important implications. As a systemic inflammatory disease, COPD may accelerate the development of CVD above and beyond that due to smoking alone. ${ }^{11}$ Indeed, if the risk were great enough, therapy directed at reducing cardiovascular risk might be indicated in COPD patients even without evidence of concomitant CVD, or the presence of other known risk factors aside from smoking.

This study used data from the National Health Interview Survey (NHIS), a representative sample of the civilian, noninstitutionalized, adult US population to investigate the association between COPD and CVD. Our aims were: 1) To measure prevalence of CVDs in COPD patients; 2) to determine if the diagnosis of COPD is an independent risk factor for CVD after adjusting for major sociodemographic, lifestyle, and comorbidity risk factors, including physical activity, alcohol consumption, and smoking; 3) to stratify COPD as a CVD risk factor in different age and gender groups; 4) to determine in a case-control study whether COPD plays a role as an independent risk for cardiovascular morbidity amplifying effect of smoking. We hypothesized that the diagnosis of "COPD" increases the risk of having CVD, independently of smoking history, age, gender, and lifestyle risks known to lead to CVD.

\section{Methods}

\section{Study setting and sample}

Data from the sample adult core of 2002 NHIS $^{15}$ were analyzed. The value of the NHIS data set lies in the design of its field instrument which permits the collection of a broad range of demographic, socioeconomic, and health behavior data along with the prevalence of illness and disability. ${ }^{16}$ For the sample adult core, one adult per family was randomly selected to complete a computer-assisted personal interview. The NHIS provides final weights accounting for a complex sampling design and allowing population-based estimates. Though the NHIS collected self-reported data, previous studies have confirmed the validity and analysis of this type of data. ${ }^{17-20}$ In this study all subjects 18 years and older were included in analyses. Subjects with missing data who did not ascertained, refused, or did not know responses were excluded from analyses.

\section{CVD status}

CVD status was the primary outcome variable of interest. Subjects were asked whether a doctor or other health professional told them that they had congestive heart failure, poor circulation in legs, stroke, coronary heart disease, angina (angina pectoris), irregular heartbeats, or heart attack (myocardial infarction). Subjects who answered yes to at least one of these questions were considered to have CVD. Subjects who answered no to all these conditions were considered not to have CVD. Subjects who answered neither "yes" nor "no" to these conditions were excluded from analysis. In addition to defining "CVD" as above, we defined as outcomes each of the individual conditions above.

\section{COPD status}

COPD status was ascertained based on the following questions: "Have you ever been told by a doctor or other health professional that you had emphysema?" and "During the past 12 months, have you been told by a doctor or other health professional that you had chronic bronchitis?" Subjects' reports of what they were told by physicians may not necessarily correspond to the strict medical definition of COPD (eg, GOLD criteria). To take this into account we analyzed the data using three different definitions of "COPD" of increasing strictness: 1) Subjects report having "chronic bronchitis" and/or "emphysema"; 2) Same as \#1 and are $\geq 40$ years old; 3 . Same as \#2 and report smoking more than 100 cigarettes in their lifetime. The last definition we felt to be the most likely to correspond to the medical definition of COPD and results based on this definition are reported below. The two less stringent definitions (1 and 2) lead to similar results and conclusions. To characterize the study population, the COPD status was further subcategorized as: not having COPD, having chronic bronchitis alone, 
having emphysema alone, or having both chronic bronchitis and emphysema.

\section{Risk factors}

Sociodemographic variables included age, gender, race/ ethnicity, marital status, education level and family income. Race/ethnicity was categorized into: White, Black, Hispanic, and other. Subjects with spouse or partner living together were considered as married. Education level was divided into three groups: had $<12$ years education, graduated from a high school, and had $>12$ years education. Family income was dichotomized as family income less than $\$ 20,000$ and family income of $\$ 20,000$ or more.

Lifestyle variables included: tobacco use, alcohol consumption and physical activity. Tobacco use was defined as current nonsmoker and current smoker. Alcohol use was defined as nondrinkers, light, and current drinkers. Exercise status was defined as never or ever exercised. Comorbid conditions of interest included: hypertension, diabetes, hypercholesterolemia, body mass index (BMI) status (underweight $=\mathrm{BMI}<18.5$, normal $=\mathrm{BMI} 18.5-25$, overweight $=\mathrm{BMI}>25$ ).

\section{Statistical analysis}

All statistical analyses were performed using SAS software (version 9.1; SAS Institute, Cary, NC, USA). Sampling weights were used where applicable to adjust for the population-based multistage sampling design. ${ }^{21,22}$ To incorporate the complex sampling design of the NHIS in the statistical analysis and to generate data representative of the entire US population, SAS procedures SURVEYFREQ and SURVEYLOGISTIC were utilized. ${ }^{23}$ Chi-squared tests were employed to compare the prevalence of CVDs in COPD and non-COPD population. In addition, the prevalence of each individual category of CVDs in COPD, non-COPD subjects and non-COPD smokers were also compared.

For cohort analysis, a series of multivariate logistic regressions were performed to assess the association between any CVD, individual CVD categories and COPD, controlling for sociodemographic factors (age, gender, race, marital status, education, and family income), health behaviors (physical activity, alcohol consumption and current tobacco use) and comorbidities (hypertension, diabetes, hypercholesterolemia and obesity). The results were reported as odds ratios (OR) with corresponding 95\% confidence intervals (CI). Furthermore, stratified analyses were utilized to evaluate the impact of COPD on CVD in different age and gender groups. Age was categorized into two adult groups aged $40-60$ and $>60$ years. Interactions between age group and COPD status, and gender and COPD status were also tested.

Smoking is a risk factor common to both CVD and COPD. To further explore the possibility that COPD is a risk for CVD independent of smoking, we performed a matched case-control study drawn from the NHIS 2002 data set in which COPD was considered as an exposure factor. For this purpose we limited our analysis data set to only subjects $\geq 40$ years old who smoked more than 100 cigarettes in their lifetime (smokers). Cases were defined as smokers of age 40 years and older who had at least one CVD category from above. Overall, 2,975 cases were identified in the analysis data set. Each case was matched by age ( \pm 1 year), gender and race with a control represented by a smoker aged $\geq 40$ years who did not have CVD and who was selected randomly from the same analysis data set. The outcome of interest was CVD, defined as having at least one of the CVD categories above. Regression analysis for matched casecontrol studies was used to estimate the association of CVD and COPD. ${ }^{24}$ Conditional logistic regression was employed to estimate the hazard ratio (HR) and 95\% CI adjusting for matched variables and other sociodemographic, lifestyle, and comorbid risk factors.

\section{Results}

Table 1 shows the characteristics of our study population. There were 18,342 subjects who were aged $\geq 40$ years in our cohort and did not have any missing data. Study subjects were mostly white (78\%), women (53\%) with an average age of 57 years. Most subjects were married (69\%) and had higher education (51\%). About 5\% of the subjects had COPD and over $28 \%$ of the subjects had CVD. Subjects who had CVD and COPD were older and had lower family income, tended to smoke and do less exercise.

Table 2 lists the prevalence of CVD in COPD, as well as various COPD subgroups. Fifty-six percent of COPD patients had CVD, while only $26 \%$ of the non-COPD subjects had CVD, $(P<0.0001)$. Subjects who reported both chronic bronchitis and emphysema were more likely to have CVD than subjects who reported no COPD, chronic bronchitis alone or emphysema alone $(P<0.0001)$.

Table 3 presents the breakdown of individual CVD categories. Poor circulation in legs and irregular heartbeats were two common conditions in COPD subjects (34\% and $29 \%$, respectively), as well as in non-COPD patients $(12 \%$ and $12 \%$, respectively) and non-COPD smokers (13\% and $13 \%$, respectively). Sixteen percent of COPD patients had 
Table I Characteristics of the study population*

\begin{tabular}{|c|c|c|c|c|c|c|c|}
\hline Variables & $\begin{array}{l}\text { All population } \\
\begin{array}{l}\mathrm{N}=18,342 \\
\% \text { (SE) }\end{array}\end{array}$ & $\begin{array}{l}\text { COPD } \\
\begin{array}{l}\mathbf{N}=958 \\
\%(\mathrm{SE})\end{array}\end{array}$ & $\begin{array}{l}\text { Bronchitis and } \\
\text { emphysema } \\
N=139 \\
\% \text { (SE) }\end{array}$ & $\begin{array}{l}\text { Bronchitis } \\
\text { alone } \\
N=514 \\
\% \text { (SE) }\end{array}$ & $\begin{array}{l}\text { Emphysema } \\
\text { alone } \\
\mathbf{N}=305 \\
\%(\mathrm{SE})\end{array}$ & $\begin{array}{l}\text { COPD and } \\
\text { CVD } \\
N=557 \\
\% \text { (SE) }\end{array}$ & $\begin{array}{l}\text { CVD } \\
N=5,242 \\
\% \text { (SE) }\end{array}$ \\
\hline Age (mean, SE) & $\begin{array}{l}56.8 \\
(0.1)\end{array}$ & $\begin{array}{l}60.3 \\
(0.4)\end{array}$ & $\begin{array}{l}61.7 \\
(0.6)\end{array}$ & $\begin{array}{l}56.5 \\
(0.5)\end{array}$ & $\begin{array}{l}66.3 \\
(0.5)\end{array}$ & $\begin{array}{l}62.8 \\
(0.5)\end{array}$ & $\begin{array}{l}63.2 \\
(0.2)\end{array}$ \\
\hline \multicolumn{8}{|l|}{ Gender } \\
\hline Female & $\begin{array}{l}47.0 \\
(0.4) \\
53.0 \\
(0.4)\end{array}$ & $\begin{array}{l}45.5 \\
(1.6) \\
54.5 \\
(1.6)\end{array}$ & $\begin{array}{l}46.4 \\
(1.9) \\
53.6 \\
(1.9)\end{array}$ & $\begin{array}{l}34.1 \\
(1.8) \\
65.9 \\
(1.8)\end{array}$ & $\begin{array}{l}65.3 \\
(2.1) \\
34.7 \\
(2.1)\end{array}$ & $\begin{array}{l}44.4 \\
(1.8) \\
55.6 \\
(1.8)\end{array}$ & $\begin{array}{l}46.4 \\
(0.8) \\
53.6 \\
(0.8)\end{array}$ \\
\hline \multicolumn{8}{|l|}{ Race } \\
\hline White & $\begin{array}{l}77.8 \\
(0.5)\end{array}$ & $\begin{array}{l}85.4 \\
(I .1)\end{array}$ & $\begin{array}{l}95.6 \\
(0.1)\end{array}$ & $\begin{array}{l}80.3 \\
(1.4)\end{array}$ & $\begin{array}{l}89.6 \\
(1.2)\end{array}$ & $\begin{array}{l}83.0 \\
(1.4)\end{array}$ & $\begin{array}{l}78.9 \\
(0.7)\end{array}$ \\
\hline Black & $\begin{array}{l}10.1 \\
(0.3)\end{array}$ & $\begin{array}{l}8.8 \\
(0.8)\end{array}$ & $\begin{array}{l}1.5 \\
(0.04)\end{array}$ & $\begin{array}{l}11.7 \\
(0.9)\end{array}$ & $\begin{array}{l}7.0 \\
(0.9)\end{array}$ & $\begin{array}{l}10.7 \\
(1.0)\end{array}$ & $\begin{array}{l}10.9 \\
(0.5)\end{array}$ \\
\hline Hispanic & $\begin{array}{l}8.4 \\
(0.3)\end{array}$ & $\begin{array}{l}4.1 \\
(0.8)\end{array}$ & $\begin{array}{l}1.4 \\
(0.04)\end{array}$ & $\begin{array}{l}5.9 \\
(1.1)\end{array}$ & $\begin{array}{l}2.3 \\
(0.2)\end{array}$ & $\begin{array}{l}4.8 \\
(1.1)\end{array}$ & $\begin{array}{l}7.1 \\
(0.4)\end{array}$ \\
\hline Other & $\begin{array}{l}3.7 \\
(0.2)\end{array}$ & $\begin{array}{l}1.7 \\
(0.4)\end{array}$ & $\begin{array}{l}1.5 \\
(0.04)\end{array}$ & $\begin{array}{l}2.1 \\
(0.7)\end{array}$ & $\begin{array}{l}\text { I.I } \\
(0.6)\end{array}$ & $\begin{array}{l}1.5 \\
(0.4)\end{array}$ & $\begin{array}{l}3.1 \\
(0.3)\end{array}$ \\
\hline \multicolumn{8}{|l|}{ Marital status } \\
\hline $\begin{array}{l}\text { Spouse/partner } \\
\text { present } \\
\text { Nonspouse/partner } \\
\text { present }\end{array}$ & $\begin{array}{l}68.6 \\
(0.4) \\
31.4 \\
(0.4)\end{array}$ & $\begin{array}{l}57.8 \\
(1.4) \\
42.2 \\
(1.4)\end{array}$ & $\begin{array}{l}52.8 \\
(2.4) \\
47.2 \\
(2.4)\end{array}$ & $\begin{array}{l}60.0 \\
(1.6) \\
40.0 \\
(1.6)\end{array}$ & $\begin{array}{l}56.3 \\
(1.8) \\
43.7 \\
(1.8)\end{array}$ & $\begin{array}{l}54.5 \\
(1.7) \\
45.5 \\
(1.7)\end{array}$ & $\begin{array}{l}62.5 \\
(0.8) \\
37.5 \\
(0.8)\end{array}$ \\
\hline \multicolumn{8}{|l|}{ Education } \\
\hline$<12$ years & $\begin{array}{l}15.8 \\
(0.3)\end{array}$ & $\begin{array}{l}26.6 \\
(1.3)\end{array}$ & $\begin{array}{l}42.1 \\
(1.9)\end{array}$ & $\begin{array}{l}18.1 \\
(1.7)\end{array}$ & $\begin{array}{l}34.3 \\
(2.1)\end{array}$ & $\begin{array}{l}32.9 \\
(1.8)\end{array}$ & $\begin{array}{l}24.2 \\
(0.7)\end{array}$ \\
\hline$=12$ years & $\begin{array}{l}33.5 \\
(0.4)\end{array}$ & $\begin{array}{l}36.4 \\
(1.5)\end{array}$ & $\begin{array}{l}29.8 \\
(1.8)\end{array}$ & $\begin{array}{l}37.5 \\
(1.9)\end{array}$ & $\begin{array}{l}37.5 \\
(2.4)\end{array}$ & $\begin{array}{l}35.3 \\
(1.8)\end{array}$ & $\begin{array}{l}33.8 \\
(0.8)\end{array}$ \\
\hline$>12$ years & $\begin{array}{l}50.7 \\
(0.5)\end{array}$ & $\begin{array}{l}37.0 \\
(1.5)\end{array}$ & $\begin{array}{l}28.1 \\
(1.9)\end{array}$ & $\begin{array}{l}44.4 \\
(1.9)\end{array}$ & $\begin{array}{l}28.2 \\
(1.9)\end{array}$ & $\begin{array}{l}31.8 \\
(1.8)\end{array}$ & $\begin{array}{l}42.0 \\
(0.8)\end{array}$ \\
\hline \multicolumn{8}{|l|}{ Family income } \\
\hline Below $20 \mathrm{~K}$ & $\begin{array}{l}19.2 \\
(0.4)\end{array}$ & $\begin{array}{l}34.4 \\
(1.4)\end{array}$ & $\begin{array}{l}47.5 \\
(2.1)\end{array}$ & $\begin{array}{l}28.0 \\
(1.6)\end{array}$ & $\begin{array}{l}39.4 \\
(2.3)\end{array}$ & $\begin{array}{l}41.6 \\
(1.8)\end{array}$ & $\begin{array}{l}29.3 \\
(0.8)\end{array}$ \\
\hline Above $20 \mathrm{~K}$ & $\begin{array}{l}80.8 \\
(0.4)\end{array}$ & $\begin{array}{l}65.6 \\
(1.4)\end{array}$ & $\begin{array}{l}52.5 \\
(2.1)\end{array}$ & $\begin{array}{l}72.0 \\
(1.6)\end{array}$ & $\begin{array}{l}60.6 \\
(2.3)\end{array}$ & $\begin{array}{l}58.4 \\
(1.8)\end{array}$ & $\begin{array}{l}70.7 \\
(0.8)\end{array}$ \\
\hline \multicolumn{8}{|l|}{ BMI } \\
\hline $\begin{array}{l}\text { Underweight } \\
(\mathrm{BMI}<18.5)\end{array}$ & $\begin{array}{l}1.4 \\
(0.1)\end{array}$ & $\begin{array}{l}3.8 \\
(0.6)\end{array}$ & $\begin{array}{l}4.6 \\
(0.1)\end{array}$ & $\begin{array}{l}1.9 \\
(0.4)\end{array}$ & $\begin{array}{l}6.8 \\
(1.1)\end{array}$ & $\begin{array}{l}3.8 \\
(0.6)\end{array}$ & $\begin{array}{l}2.0 \\
(0.18)\end{array}$ \\
\hline $\begin{array}{l}\text { Normal } \\
(18.5 \leq \mathrm{BMI}<25)\end{array}$ & $\begin{array}{l}33.2 \\
(0.4)\end{array}$ & $\begin{array}{l}31.9 \\
(1.4)\end{array}$ & $\begin{array}{l}33.9 \\
(2.2)\end{array}$ & $\begin{array}{l}28.0 \\
(1.6)\end{array}$ & $\begin{array}{l}37.9 \\
(2.2)\end{array}$ & $\begin{array}{l}30.4 \\
(1.6)\end{array}$ & $\begin{array}{l}29.6 \\
(0.8)\end{array}$ \\
\hline Overweight (BMI $\geq 25$ ) & $\begin{array}{l}65.4 \\
(0.5)\end{array}$ & $\begin{array}{l}64.3 \\
(1.5)\end{array}$ & $\begin{array}{l}61.5 \\
(2.2)\end{array}$ & $\begin{array}{l}70.1 \\
(1.7)\end{array}$ & $\begin{array}{l}55.3 \\
(2.2)\end{array}$ & $\begin{array}{l}65.8 \\
(1.7)\end{array}$ & $\begin{array}{l}68.4 \\
(0.8)\end{array}$ \\
\hline \multicolumn{8}{|l|}{ Smoking status } \\
\hline Nonsmoker currently & $\begin{array}{l}80.1 \\
(0.4)\end{array}$ & $\begin{array}{l}53.7 \\
(1.7)\end{array}$ & $\begin{array}{l}44.5 \\
(2.4)\end{array}$ & $\begin{array}{l}52.9 \\
(2.0)\end{array}$ & $\begin{array}{l}59.6 \\
(2.5)\end{array}$ & $\begin{array}{l}45.5 \\
(1.7)\end{array}$ & $\begin{array}{l}80.4 \\
(0.6)\end{array}$ \\
\hline Current smoker & $\begin{array}{l}19.9 \\
(0.3)\end{array}$ & $\begin{array}{l}46.3 \\
(1.7)\end{array}$ & $\begin{array}{l}55.5 \\
(2.4)\end{array}$ & $\begin{array}{l}47.1 \\
(2.0)\end{array}$ & $\begin{array}{l}40.4 \\
(2.5)\end{array}$ & $\begin{array}{l}54.5 \\
(1.7)\end{array}$ & $\begin{array}{l}19.6 \\
(0.6)\end{array}$ \\
\hline \multicolumn{8}{|l|}{ Drinking status } \\
\hline Nondrinker & $\begin{array}{l}22.1 \\
(0.4)\end{array}$ & $\begin{array}{l}11.7 \\
(1.0)\end{array}$ & $\begin{array}{l}10.9 \\
(1.9)\end{array}$ & $\begin{array}{l}12.5 \\
(1.3)\end{array}$ & $\begin{array}{l}10.8 \\
(1.4)\end{array}$ & $\begin{array}{l}12.6 \\
(1.2)\end{array}$ & $\begin{array}{l}24.0 \\
(0.7)\end{array}$ \\
\hline Light drinker & $\begin{array}{l}50.3 \\
(0.5)\end{array}$ & $\begin{array}{l}52.6 \\
(1.6)\end{array}$ & $\begin{array}{l}52.9 \\
(1.9)\end{array}$ & $\begin{array}{l}57.3 \\
(1.7)\end{array}$ & $\begin{array}{l}44.0 \\
(2.5)\end{array}$ & $\begin{array}{l}50.8 \\
(1.9)\end{array}$ & $\begin{array}{l}47.2 \\
(0.9)\end{array}$ \\
\hline Drinker & $\begin{array}{l}27.6 \\
(0.4)\end{array}$ & $\begin{array}{l}35.7 \\
(1.6)\end{array}$ & $\begin{array}{l}36.2 \\
(1.7)\end{array}$ & $\begin{array}{l}30.2 \\
(1.6)\end{array}$ & $\begin{array}{l}45.2 \\
(2.6)\end{array}$ & $\begin{array}{l}36.6 \\
(1.8)\end{array}$ & $\begin{array}{l}28.8 \\
(0.8)\end{array}$ \\
\hline
\end{tabular}


Table I (Continued)

\begin{tabular}{|c|c|c|c|c|c|c|c|}
\hline \multirow[t]{3}{*}{ Variables } & All population & COPD & $\begin{array}{l}\text { Bronchitis and } \\
\text { emphysema }\end{array}$ & $\begin{array}{l}\text { Bronchitis } \\
\text { alone }\end{array}$ & $\begin{array}{l}\text { Emphysema } \\
\text { alone }\end{array}$ & $\begin{array}{l}\text { COPD and } \\
\text { CVD }\end{array}$ & CVD \\
\hline & $N=18,342$ & $\mathbf{N}=958$ & $N=139$ & $N=514$ & $\mathbf{N}=305$ & $N=557$ & $N=5242$ \\
\hline & $\%(\mathrm{SE})$ & $\%$ (SE) & $\%$ (SE) & $\%$ (SE) & $\%$ (SE) & $\%$ (SE) & $\%$ (SE) \\
\hline \multicolumn{8}{|l|}{ Exercise } \\
\hline \multirow[t]{2}{*}{ Never } & 41.2 & 57.0 & 73.3 & 48.9 & 63.4 & 62.4 & 49.0 \\
\hline & $(0.6)$ & (I.7) & (I.4) & $(2.1)$ & $(2.0)$ & (I.8) & $(0.9)$ \\
\hline \multirow[t]{2}{*}{ Ever } & 58.8 & 43.0 & 26.7 & 51.1 & 36.6 & 37.6 & 51.0 \\
\hline & $(0.6)$ & (1.7) & (I.4) & (2.I) & $(2.0)$ & (I.8) & $(0.9)$ \\
\hline
\end{tabular}

Notes: *COPD definition was based on subject reporting (I) “chronic bronchitis" and/or "emphysema”; (2) age > = 40 years old; (3) smoking more than I00 cigarettes in their lifetime.

Abbreviations: BMI, body mass index; COPD, chronic obstructive pulmonary disease; CVD, cardiovascular disease; SE, standard error.

coronary heart disease, compared to $6 \%$ of non-COPD patients and $7 \%$ of non-COPD smokers. The difference was statistically significant $(P<0.0001)$. In all, subjects with COPD were more likely to report any individual CVD category than non-COPD patients and non-COPD smokers.

Table 4 shows the association between COPD and any CVD and individual CVD categories adjusting for sociodemographic factors, health behavior factors and comorbidities in multivariate regression model. Subjects with COPD had more than twice the risk of CVD than subjects without COPD (OR 2.7, 95\% CI: 2.3-3.2). Older age, lower family income, underweight, smoking, drinking, diabetes, hypertension, and high cholesterol were significantly associated with increased risk of CVD; while being Hispanic, having higher education and exercise were associated with significantly reduced the risk of CVD. Furthermore, COPD was significantly associated with all individual definitions of CVD categories. Among them, COPD reveals the strongest association with congestive heart failure (OR 3.9, 95\% CI: 2.8-5.5). As well, age, education, income, exercise, and comorbidities including diabetes, hypertension and high cholesterol indicated consistent relation with each individual CVD categories.

Table 5 presents the association of COPD with any CVD and individual CVD categories stratified by age and gender.
The adjusted OR of CVD was three times higher in subjects with COPD compared to those without COPD among subjects aged from 40 to 60 years, while the OR of CVD was twice as high for subjects aged 60 years and older. The difference is statistically significant $(P=0.0149)$. Moreover, the ORs for myocardial infarction and irregular heart beat were greater in subjects aged 40-60 years than for subjects aged $>60$ years. In gender-related differences, there was no significant difference between ORs for CVD or any CVD category except for coronary heart disease, which was significantly greater in females than in males.

Comparative analysis of health care utilization in COPD and CVD subjects was performed to assess affect of concurrent COPD and CVD conditions on urgent care utilization, hospital stay, doctor office visits, and days missing work. About $45 \%$ of subjects with both COPD and CVD visited the emergency room more than once during the past 12 months compared to $38 \%$ of COPD patients and $32 \%$ of CVD patients. Patients who had COPD and CVD tended to have more doctor visits during past 12 months than subjects with COPD alone and CVD alone. The mean number of days missing work at a job for subjects with COPD and CVD was 22 days, compared to 13 days for subjects with COPD alone and 10 days for subjects with CVD alone. Overall, subjects who had COPD and CVD had higher health care utilization

Table 2 CVD prevalence in different COPD categories

\begin{tabular}{|c|c|c|c|c|c|}
\hline \multirow[t]{3}{*}{ Variables } & COPD & Non-COPD & $\begin{array}{l}\text { Bronchitis and } \\
\text { emphysema }\end{array}$ & $\begin{array}{l}\text { Bronchitis } \\
\text { alone }\end{array}$ & $\begin{array}{l}\text { Emphysema } \\
\text { alone }\end{array}$ \\
\hline & $\mathbf{N}=958$ & $N=17,384$ & $N=139$ & $N=5 \mid 4$ & $\mathbf{N}=305$ \\
\hline & $\%$ (SE) & $\%(\mathrm{SE})$ & $\%$ (SE) & $\%$ (SE) & $\%$ (SE) \\
\hline \multirow[t]{2}{*}{$\overline{C V D}$} & 56.5 & 25.6 & 82.3 & 48.3 & 58.6 \\
\hline & (I.7) & $(0.4)$ & (3.9) & $(2.4)$ & (2.9) \\
\hline \multirow[t]{2}{*}{ Non-CVD } & 43.5 & 74.4 & 17.7 & 51.7 & 41.4 \\
\hline & (I.7) & $(0.4)$ & (3.9) & (2.4) & (2.9) \\
\hline
\end{tabular}

Abbreviations: COPD, chronic obstructive pulmonary disease; CVD, cardiovascular disease; SE, standard error. 
Table 3 Prevalence of CVD categories in COPD, non-COPD, and non-COPD smokers

\begin{tabular}{|c|c|c|c|c|c|}
\hline Variables & $\begin{array}{l}\% \text { in COPD (SE) } \\
\mathbf{N}=958\end{array}$ & $\begin{array}{l}\% \text { in non-COPD (SE) } \\
\mathbf{N}=\mathbf{I 7 , 3 8 4}\end{array}$ & $\mathbf{P} *$ & $\begin{array}{l}\% \text { in non-COPD } \\
\text { smokers (SE) } \\
N=\mathbf{8 , 2 2 0}\end{array}$ & $\mathbf{P} *$ \\
\hline Coronary heart disease & I6.I (I.3) & $6.1(0.2)$ & $<0.0001$ & $7.5(0.3)$ & $<0.000$ I \\
\hline Angina (Angina pectoris) & II.7 (I.2) & $3.9(0.2)$ & $<0.0001$ & $4.8(0.3)$ & $<0.000$ I \\
\hline Myocardial infarction & I4.8 (I.3) & $4.8(0.2)$ & $<0.0001$ & $6.1(0.3)$ & $<0.000$ I \\
\hline Stroke & $8.0(1.0)$ & $3.6(0.2)$ & $<0.0001$ & $4.1(0.2)$ & 0.0002 \\
\hline Congestive heart failure & II.4 (I.3) & $2.4(0.1)$ & $<0.0001$ & $2.7(0.2)$ & $<0.000$ I \\
\hline Poor circulation in legs & $33.8(1.9)$ & I2.I (0.3) & $<0.0001$ & $13.5(0.4)$ & $<0.000$ I \\
\hline Irregular heart beat & $29.0(1.6)$ & $12.0(0.3)$ & $<0.0001$ & I $2.7(0.4)$ & $<0.0001$ \\
\hline
\end{tabular}

Note: *Wald Chi-squared test.

Abbreviations: COPD, chronic obstructive pulmonary disease; CVD, cardiovascular disease; SE, standard error.

than subjects who had COPD alone, and subjects with COPD alone had higher health care utilization than subjects with CVD alone.

The number of concurrent CVD conditions in COPD patients with CVD and patients without COPD who had CVD has been assessed. Forty-six percent of the subjects with COPD and CVD had just one category of CVD, compared to $57 \%$ of subjects who smoked, had CVD and no COPD. Eighteen percent of the subjects with COPD and CVD had more than three CVD categories, compared to $11 \%$ of those CVD, non-COPD smokers. The distribution was statistically different between two groups $(P<0.0001)$. Thus, patients with COPD (by definition all smokers) were more likely to have more categories of CVD than smokers without COPD.

The unadjusted OR and adjusted HR of having CVD in COPD were calculated in the matched case-control study of smokers with and without CVD. The sample was limited to the subjects whose age $\geq 40$ and who smoked $>100$ cigarettes in their lifetime. Cases were those who had either CVD category, controls were those who did not have any CVD. Cases and controls were matched on age, gender and race. There were 2,975 subjects in each group. Seventy-one percent of COPD patients had CVD compared to $47 \%$ of patients without COPD. The unadjusted OR of CVD was about threefold higher in patients with COPD than those without COPD (OR 2.9, 95\% CI: 2.4-3.4). Furthermore, COPD was independently and positively associated with CVD after adjusting for sociodemographic factors, health behavior factors and comorbidities. Patients who had COPD had a 2.5 times higher risk of CVD than those without COPD (Table 6). Lower family income, drinking and comorbidities including diabetes, hypertension and high cholesterol were significantly related the increased the risk of CVD.
Exercise and higher education as well were associated with $30 \%$ and $40 \%$ lower risk of CVD respectively compared to those who never exercise and had less than 12 years education. Current smokers were more likely to have CVD than those who did not smoke currently. However this difference was not statistically significant $(P=0.85)$.

\section{Discussion}

Our results showed that COPD diagnosis remains a strong independent predictor of CVD after adjusting for sociodemographic, lifestyle, and comorbid risk factors. This study included patients from all strata of life and thus it is likely to represent the general population. To the best of our knowledge, this is the largest cohort of US patients studied in which simultaneous adjustment for known sociodemographic and behavioral factors and comorbidities associated with CVD morbidity was carried out. This is also the first study which was able to separate the independent effect of COPD on CVD morbidity from effect of smoking by using a casecontrol design. Lastly, the impact of COPD as an independent risk factor for CVD on the entire US population has not been previously determined.

The association between COPD and CVD was evaluated in our study using NHIS, which is a representative sample of the civilian adult population in the US. First, we measured the population-based prevalence of CVD in COPD patients, and then evaluated if the diagnosis of COPD is an independent risk factor for CVD after adjusting for major sociodemographic, lifestyle, and comorbid risk factors. Secondly, in our case-control study, smokers with CVD (cases) were matched with smokers without CVD (controls) by age, race/ethnicity, and gender. This allowed separate the cardiovascular effects of smoking from the effects of COPD that was considered an exposure factor in the analysis of the case-control study. 


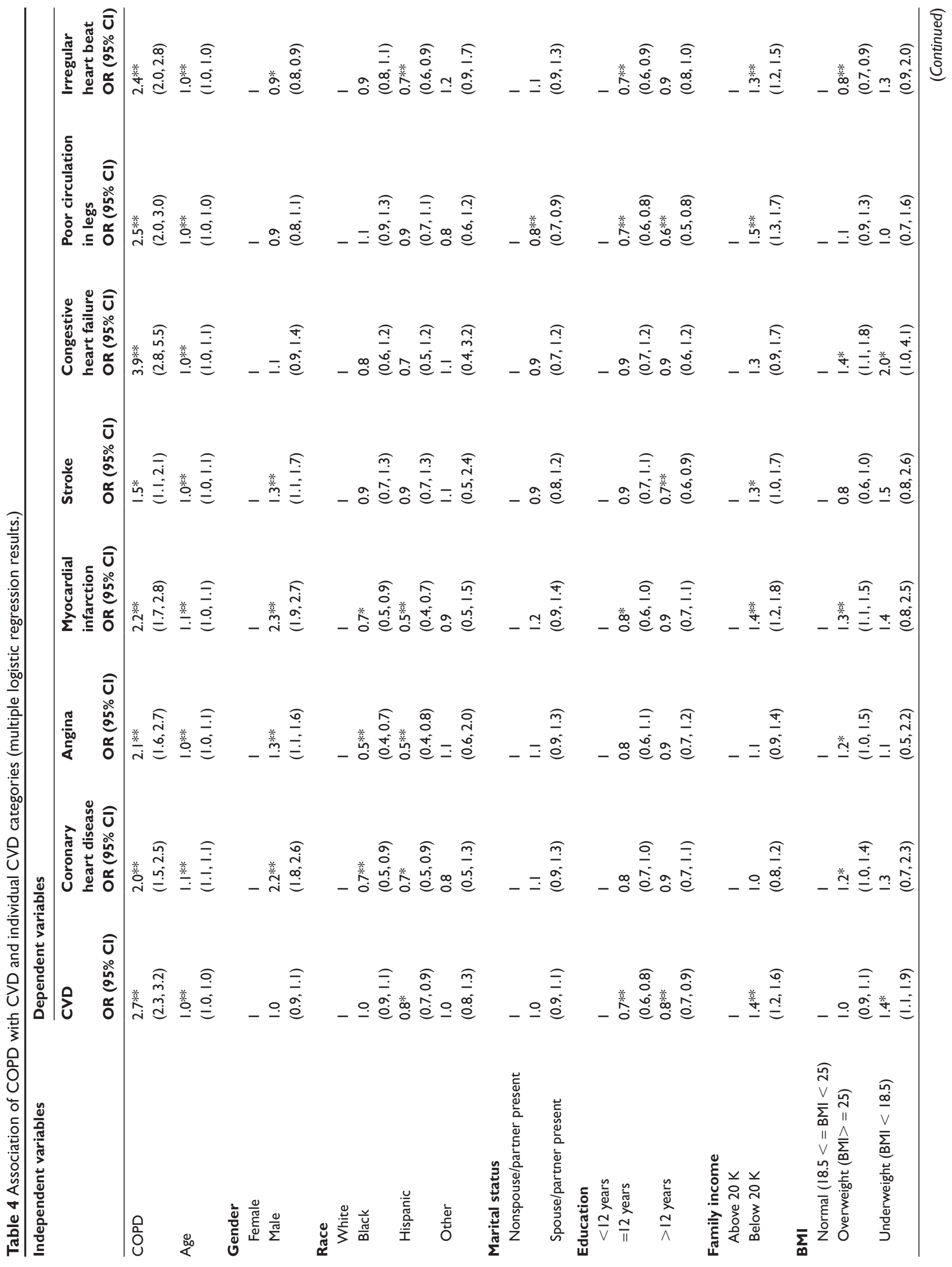




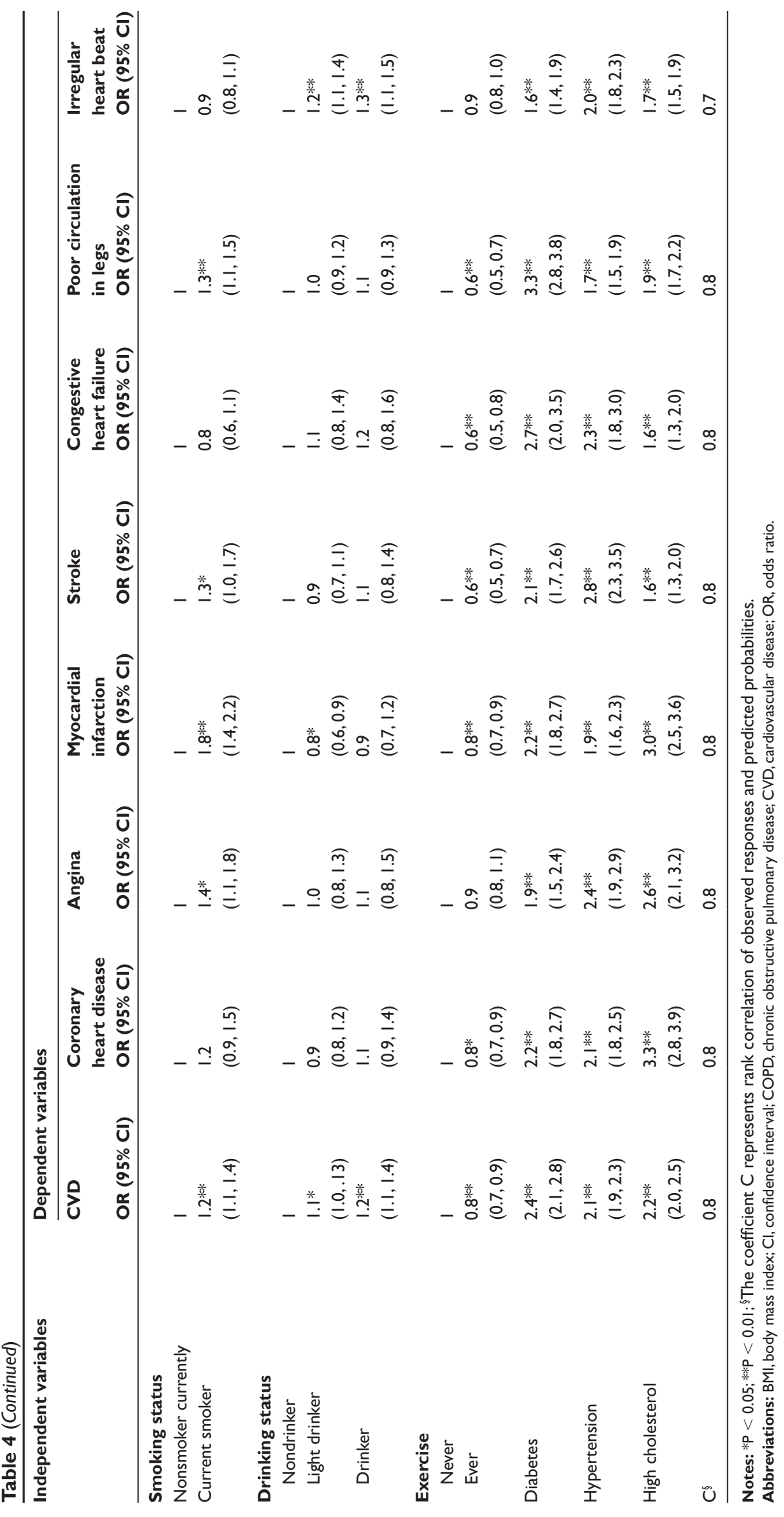


Table 5 Stratified analysis: Odds ratios of CVD and individual CVD categories by age and gender

\begin{tabular}{|c|c|c|c|c|c|c|}
\hline Variables & $\begin{array}{l}40-60 \\
N=I I, 232\end{array}$ & $\begin{array}{l}>60 \\
N=7,110\end{array}$ & $\mathbf{P}^{\dagger}$ & $\begin{array}{l}\text { Male } \\
N=7,847\end{array}$ & $\begin{array}{l}\text { Female } \\
N=10,495\end{array}$ & $\mathbf{P}^{\dagger}$ \\
\hline Any CVD & $\begin{array}{l}3 . I^{* *} \\
(2.4,4.0)\end{array}$ & $\begin{array}{l}2.2 * * \\
(1.7,2.7)\end{array}$ & 0.01 & $\begin{array}{l}2.2 * * \\
(1.6,2.9)\end{array}$ & $\begin{array}{l}3.2 * * \\
(2.5,4.0)\end{array}$ & 0.08 \\
\hline Coronary heart disease & $\begin{array}{l}2.2^{* *} \\
(1.3,3.4)\end{array}$ & $\begin{array}{l}\text { I.8** } \\
(1.4,2.3)\end{array}$ & 0.06 & $\begin{array}{l}\text { I.5* } \\
(I . I, 2.2)\end{array}$ & $\begin{array}{l}2.5^{* *} \\
(1.8,3.6)\end{array}$ & 0.009 \\
\hline Angina (Angina pectoris) & $\begin{array}{l}2.3 * * \\
(1.4,3.8)\end{array}$ & $\begin{array}{l}\text { I.8** } \\
(1.3,2.5)\end{array}$ & 0.06 & $\begin{array}{l}1.9 * * \\
(1.4,2.7)\end{array}$ & $\begin{array}{l}2.1 * * \\
(1.4,3.2)\end{array}$ & 0.6 \\
\hline Myocardial infarction & $\begin{array}{l}2.8^{* *} \\
(1.8,4.5)\end{array}$ & $\begin{array}{l}1.7 * * \\
(1.3,2.4)\end{array}$ & 0.009 & $\begin{array}{l}\text { I.8** } \\
(1.2,2.5)\end{array}$ & $\begin{array}{l}2.7 * * \\
(1.8,3.9)\end{array}$ & 0.08 \\
\hline Stroke & $\begin{array}{l}1.1 \\
(0.6,2.2)\end{array}$ & $\begin{array}{l}1.6^{*} \\
(1.1,2.3)\end{array}$ & 0.8 & $\begin{array}{l}1.6 \\
(0.9,2.5)\end{array}$ & $\begin{array}{l}1.4 \\
(0.8,2.3)\end{array}$ & 0.9 \\
\hline Congestive heart failure & $\begin{array}{l}5.2^{* *} \\
(2.9,9.1)\end{array}$ & $\begin{array}{l}3 . I^{* *} \\
(2 . I, 4.7)\end{array}$ & 0.1 & $\begin{array}{l}4.1^{* *} \\
(2.5,6.6)\end{array}$ & $\begin{array}{l}3.5^{* *} \\
(2.3,5.6)\end{array}$ & 0.6 \\
\hline Poor circulation in legs & $\begin{array}{l}2.6 * * \\
(1.9,3.5)\end{array}$ & $\begin{array}{l}2.2^{* *} \\
(1.7,2.8)\end{array}$ & 0.1 & $\begin{array}{l}1.9 * * \\
(1.4,2.6)\end{array}$ & $\begin{array}{l}2.9 * * \\
(2.2,3.8)\end{array}$ & 0.05 \\
\hline Irregular heart beat & $\begin{array}{l}2.8^{* *} \\
(2.1,3.7)\end{array}$ & $\begin{array}{l}1.9 * * \\
(1.5,2.5)\end{array}$ & 0.03 & $\begin{array}{l}2.1^{* *} \\
(1.6,2.8)\end{array}$ & $\begin{array}{l}2.6 * * \\
(2.0,3.3)\end{array}$ & 0.4 \\
\hline
\end{tabular}

Notes: tWald Chi-squared statistics; *P $<0.05$; **P $<0.01$.

Abbreviation: CVD, cardiovascular disease.

After adjusting for known factors associated with CVD morbidity, such as socioeconomic status, marital status, education, alcohol consumption, exercise, and concomitant conditions including diabetes, hypertension, obesity and hypercholesterolemia, COPD diagnosis was still a strong predictor of CVD morbidity.

The results of this study are critical given the facts known about the pathogenesis of COPD and CVD and the increased prevalence of both disease processes within the general population. Other studies support the view that COPD is an independent risk factor for CVD. Studies by Sin and colleagues ${ }^{5,25}$ showed that the lower the $\mathrm{FEV}_{1}$, the higher the risk of CVD. Sin and colleagues defined COPD as a reduced $\mathrm{FEV}_{1}$, which is a good indicator but is not specific only to COPD. Similar results were reported by Engstrom and colleagues who showed that reduced lung function predicted fatality in future cardiac events in a population-based study from Sweden. ${ }^{26}$ There was no determination of the reversibility of the airway obstruction in both of these studies. Curkendall and colleagues ${ }^{6}$ showed that the diagnosis of COPD increased the morbidity and mortality of CVD using a provincial health care database from Canada. This study did not fully evaluate the simultaneous impact of sociodemographics or lifestyle choices, such as smoking, alcohol consumption, physical activity, and how these factors affect the association between COPD and CVD.

Our results corroborate the results obtained in previous studies evaluating impact of COPD on cardiovascular morbidity and mortality. Jousilahti and colleagues reported results from a population-based study in eastern Finland concluding that chronic bronchitis predicted the risk of coronary disease independently from major cardiovascular risk factors. ${ }^{27}$ The analysis of Saskatchewan health databases performed by Huiart and colleagues ${ }^{28}$ showed that cardiovascular morbidity and mortality rates were higher in COPD patients than in the general population. Similar results were demonstrated by Sidney and colleagues using data from a health maintenance organization in northern California. ${ }^{8}$ In this study younger patients were shown to have stronger relationship of COPD to CVD which corresponds with the findings reported in this study. Salisbury and colleagues ${ }^{29}$ showed that patients with COPD had poorer health status one year after myocardial infarction and greater mortality. This corresponds with our results showing that the subjects with both COPD and CVD have higher health services utilization as compared to the individuals with only one of these two conditions. In the Atherosclerosis Risk in Communities Study, ${ }^{30}$ an association between decreased lung function and higher prevalence of coronary heart disease was observed. This association was stronger in women, which corroborates the findings in this study.

Knowing that COPD is an independent risk factor for CVD has many repercussions. The importance of recognizing and proving the association between COPD and CVD supports employing detailed medical work-ups to consider treatment for CVD in COPD patients. A concerted effort to 
Table 6 Adjusted hazard ratio (HR) of having CVD in COPD patients based on the case-control study. The sample was limited to the subjects whose age $\geq 40$, smoked $>100$ cigarettes per lifetime. Cases were those who had either CVD category, controls were those who did not have any CVD. Cases and controls were matched on age, gender, and race

\begin{tabular}{|c|c|}
\hline Independent variables & HR $(95 \% \mathrm{Cl})$ \\
\hline COPD & $2.5^{* *}(2.1,3.1)$ \\
\hline \multicolumn{2}{|l|}{ Marital status } \\
\hline Nonspouse/partner present & 1 \\
\hline Spouse/partner present & $0.9(0.8,1.1)$ \\
\hline \multicolumn{2}{|l|}{ Education } \\
\hline$<12$ years & I \\
\hline$=12$ years & $0.6 * *(0.5,0.7)$ \\
\hline$>12$ years & $0.7^{* *}(0.6,0.8)$ \\
\hline \multicolumn{2}{|l|}{ Family income } \\
\hline Above $20 \mathrm{~K}$ & I \\
\hline Below $20 \mathrm{~K}$ & $1.2 *(1.0,1.4)$ \\
\hline \multicolumn{2}{|l|}{ BMI } \\
\hline Normal $(I 8.5 \leq \mathrm{BMI}<25)$ & I \\
\hline Overweight (BMI $\geq 25)$ & $\mathrm{I} .0(0.9, \mathrm{I} .2)$ \\
\hline Underweight (BMI < I8.5) & $1.7^{*}(1.1,2.8)$ \\
\hline \multicolumn{2}{|l|}{ Smoking status } \\
\hline Nonsmoker currently & I \\
\hline Current smoker & $1.0(0.9,1.2)$ \\
\hline \multicolumn{2}{|l|}{ Drinking status } \\
\hline Nondrinker & I \\
\hline Light drinker & $1.2^{*}(1.0,1.5)$ \\
\hline Drinker & $1.2 *(1.0,1.5)$ \\
\hline \multicolumn{2}{|l|}{ Exercise } \\
\hline Never & 1 \\
\hline Ever & $0.7^{* *}(0.6,0.8)$ \\
\hline Diabetes & $2.1^{* *}(1.8,2.5)$ \\
\hline Hypertension & $2.1^{* *}(1.8,2.4)$ \\
\hline High cholesterol & $2.3^{* *}(2.0,2.6)$ \\
\hline
\end{tabular}

Notes: $* \mathrm{P}<0.05 ; * * \mathrm{P}<0.01$.

Abbreviations: BMI, body mass index; COPD, chronic obstructive pulmonary disease; CVD, cardiovascular disease; $\mathrm{HR}$, hazard ratio.

evaluate a patient with symptomatic yet undiagnosed COPD may be essential to determine a patient's cardiovascular status. Another indication would be to use a preventive medicine approach with a COPD patient making lifestyle choices clearly protective of CVD in their future. Lastly, further investigation of systemic inflammation as a culprit in the cascade of ensuing pathology as an underlying primary factor in both COPD and CVD is warranted.

The finding that COPD increases the risk for CVD above and beyond that of smoking has potentially many important implications. It may be, for instance, that patients with COPD would do well with therapies that specifically address the risk of CVD in addition to those specifically addressing the pulmonary issues. Examples of CVD-directed therapy which could be evaluated specifically in COPD included beta blockers and cholesterol-lowering agents. Such an approach is supported by the recent study that showed that the use of statins and angiotensin-converting enzyme inhibitors prior to admission was associated with decreased mortality in subjects hospitalized with COPD exacerbations. ${ }^{31}$

Smoking, which is prevalent in up to $80 \%$ of COPD patients, is also a major risk factor for CVD. ${ }^{12}$ Stavem and colleagues found that $\% \mathrm{FEV}_{1}$ predicted was a strong independent factor of all-cause mortality in current smokers whereas it was not associated with mortality among neversmokers. ${ }^{32}$ Cigarette smoking and other environmental irritants may activate alveolar macrophages, bronchial epithelial cells, and other inflammatory cells in adults that may be genetically susceptible. They also synthesize elastases and metalloproteinases, which promote emphysematous changes and airway remodeling. Even in noncurrent smokers there was evidence of low-grade inflammation in those patients with chronic airflow limitation. ${ }^{33}$ This suggests that long after smoking cessation the inflammation persists and can still be a substantial risk factor for CVD.

It has recently been appreciated that COPD, even when considered "stable" is a systemic inflammatory disorder. Various studies have shown increased levels of inflammatory and proinflammatory biomarkers such as $\mathrm{C}$-reactive protein, vascular adhesion molecules, fibrinogen levels, reactive oxygen species, low $\mathrm{CD} 4 / \mathrm{CD} 8$ ratio, cytokines such as interleukin-6 (IL-6), IL-8 and tumor necrosis factor- $\alpha$ $(\mathrm{TNF}-\alpha){ }^{11,33}$ A recent study in weight-stable subjects with advanced emphysema showed that these patients had increased serum TNF receptor levels. ${ }^{34}$ The presence of proinflammatory biomarkers is recognized as an important factor in the pathogenesis of artherogenesis.

Several studies suggested the treatment for COPD as a possible mechanism linking COPD to CVD. ${ }^{35-37}$ Beta agonists increase cardiovascular morbidity and mortality due to direct sympathetic stimulation leading to increased heart rate, increase in contractile force, an increase in cardiac output, and changes in serum potassium and magnesium levels which affect the conduction pathways of the heart. ${ }^{38}$ Some studies have failed to show an increased risk of acute myocardial infarction and death in patients with COPD taking short- and long-acting beta agonists. ${ }^{38}$ However, in the Lung Health Study, Anthonisen and colleagues showed that patients receiving ipratropium (Atrovent) had a higher risk of arrhythmias. Recent studies provided further evidence of the association between inhaled bronchodilators (both beta agonists and anticholinergics) and cardiovascular morbidity 
and mortality. ${ }^{39-43}$ The higher risk of CVD among younger patients with COPD found in our study may be mediated by the use of inhaled bronchodilators which were shown to impose a larger relative risk in people with unrecognized CVD than in people with known disorders. ${ }^{43}$ However, the mechanism of this association including association between the use of inhaled bronchodilators and COPD morbidity and mortality was beyond the scope of this study.

The studies cited above certainly are consistent with the possibility that the added risk of CVD attributed to COPD in smokers is a manifestation of COPD associated inflammatory biomarkers. Whether this or other factors account for the added risk for CVD in COPD is unknown at this time. For example, a recent review of the cohort of the Nurses Health Study showed that COPD patients are at increased risk of type 2 diabetes, ${ }^{44}$ in turn an important risk for CVD. Another possible factor increasing the risk of CVD in COPD is autonomic instability, possibly linked to increased sympathetic drive manifested by decreased respiratory heart rate variability. ${ }^{45,46}$ Newman and colleagues showed that COPD was independently associated with increase in coronary artery calcium scores as evidenced by electron beam tomography findings. ${ }^{47}$ Recently, increased arterial stiffness was shown to be related to the severity of airflow obstruction and was suggested to be a factor in the excess risk for CVD in COPD. ${ }^{48}$ Other potential factors in COPD leading to increased CVD risk include increased oxygen consumption resulting in elevated cardiovascular stress with the need to increase peripheral oxygen delivery. ${ }^{49}$ Finally, COPD patients are likely to be more sedentary due to exercise limitation, in turn worsening their risk for CVD. ${ }^{50}$

Because the NHIS survey is based on self-reported information, it has inherent limitations. ${ }^{51}$ Detection of COPD is affected by its proper recognition by both the study participants and their physicians. The term "chronic bronchitis" in the NHIS survey may be misinterpreted as recurrent episodes of acute bronchitis. We addressed this limitation by introducing more stringent criteria for detecting COPD patients including history of smoking and aged 40 years and older since most patients with COPD present after the fifth decade with positive history of smoking. ${ }^{52}$ Overall, the NHIS survey has been administered in US on an annual basis since 1957 and was repeatedly demonstrated to provide reliable estimates of health-related outcomes in the US population. ${ }^{19,20}$ The data from the NHIS survey has been extensively used in population-based epidemiological studies related to COPD. ${ }^{53-56}$ The previous studies have established the reliability of self-reported diagnosis..$^{57,58}$ Absence of data on $\mathrm{FEV}_{1}$ may also be interpreted as a limitation. However, reduced $\mathrm{FEV}_{1}$ is not specific to $\mathrm{COPD}$ and may be manifested in other diseases such as congestive heart failure, asthma, cystic fibrosis, thoracic kyphosis, multiple sclerosis, and other conditions. ${ }^{59-61}$ At the same time FEV in mild COPD (stage 1 according to the GOLD guidelines $)^{59}$ can potentially be near normal ( $\geq 80 \%)$. Postbronchodilator $\mathrm{FEV}_{1}$ and $\mathrm{FEV}_{1} / \mathrm{FVC}$ ratio are required for accurate differential diagnosis and severity assessment of COPD, ${ }^{59}$ however these indicators are usually unavailable in administrative databases and electronic medical records, which makes it difficult to use these indices in population-based studies. In addition, recent studies established association between reduced $\mathrm{FEV}_{1}$ with nonrespiratory conditions such as stroke, cancer, hip fracture, obesity, and diabetes. ${ }^{39,62-64}$ Based on these considerations we felt that not accounting for $\mathrm{FEV}_{1}$ in our analysis did not affect the study results. As with any cross-sectional design, our study cannot report on causality or temporality.

We believe that the results of this study will increase awareness of COPD as an independent risk factor for CVD. Better understanding of this association will help us to make newer guidelines which will require us to screen for presence of COPD in all patients with heart disease and vice versa. This should lead to amendment of various guidelines, which should include control of COPD, along with control of blood pressure, low-density lipoprotein, cholesterol, and other CVD risk factors. Considering the role of inflammation in COPD, different therapies targeting this aspect may help reduce the morbidity and mortality in COPD. This will hopefully help to decrease the economic burden of this disease on our society. Our results suggest that further studies are warranted in the following domains: 1) role and mechanisms of systemic inflammation as an underlying factor leading to the higher risk of CVD in COPD patients; 2) affect of COPD medications on CVD morbidity and mortality; and 3) development of effective strategies for primary and secondary CVD prevention in patients with COPD.

\section{Disclosures}

Dr Finkelstein was supported by NIH grants HL071690 and HL078579. Dr Scharf was supported by NIH grants HL074441 and HR76190.

\section{References}

1. Petty TL. Definition, epidemiology, course and prognosis of COPD. Clin Cornerstone. 2003;5:1-10.

2. Mannino DM, Brown C, Giovino GA. Obstructive lung disease deaths in the United States from 1979 through 1993: An analysis using multiplecause mortality data. Am J Respir Crit Care Med. 1997;156:814-818. 
3. Holguin F, Folch E, Redd SC, Mannino DM. Comorbidity and mortality in COPD-related hospitalizations in the United States, 1979 to 2001. Chest. 2005;128:2005-2011.

4. Pope CA 3rd, Burnett RT, Thurston GD, et al. Cardiovascular mortality and long-term exposure to particulate air pollution. Epidemiological evidence of general pathophysiological pathways of disease. Circulation. 2004;109:71-77.

5. Sin DD, Man SFP. Chronic obstructive pulmonary disease: A novel risk factor for cardiovascular disease. Can J Physiol Pharmacol. 2005;83:8-13.

6. Curkendall SM, DeLuise C, Jones JK, et al. Cardiovascular disease in patients with chronic obstructive pulmonary disease, Saskatchewan Canada cardiovascular disease in COPD patients. Ann Epidemiol. 2006;16:63-70.

7. Soriano JB, Visick GT, Muellerova H, Payvandi N, Hansell AL. Patterns of comorbidities in newly diagnosed COPD and asthma in primary care. Chest. 2005;128:2099-2107.

8. Sidney S, Sorel M, Quesenberry CP, DeLuise C, Lanes S, Eisner MD. COPD and incident cardiovascular disease hospitalizations and mortality: Kaiser Permanente Medical Care Program. Chest. 2005;128: 2068-2075.

9. Rennard SI. Clinical approach to patients with chronic obstructive pulmonary disease and cardiovascular disease. Proc Am Thorac Soc. 2005;2:94-100.

10. Hunninghake DB. Cardiovascular disease in chronic obstructive pulmonary disease. Proc Am Thorac Soc. 2005;2(1):44-49.

11. Agustí AG, Noguera A, Sauleda J, Sala E, Pons J, Busquets X. Systemic effects of chronic obstructive pulmonary disease. Eur Respir J. 2003; 21:347-360.

12. Anthonisen NR, Connett JE, Enright PL, Manfreda J; Lung Health Study Research Group. Hospitalizations and mortality in the Lung Health Study. Am J Respir Crit Care Med. 2002;166:333-339.

13. Engström G, Hedblad B, Janzon L, Valind S. Respiratory decline in smokers and ex-smokers - an independent risk factor for cardiovascular disease and death. J Cardiovasc Risk. 2000;7:267-272.

14. Sin DD, Wu L, Man SF. The relationship between reduced lung function and cardiovascular mortality: a population-based study and a systematic review of the literature. Chest. 2005;127:1952-1959.

15. National Health Interview Survey [machine-readable data files], 2002. Available from ftp://ftp.cdc.gov/pub/Health_Statistics/NCHS/Datasets/ NHIS/2002/. Accessed on August 1, 2009.

16. National Health Interview Survey [machine-readable documentation], 2002. Available from ftp://ftp.cdc.gov/pub/Health_Statistics/NCHS/ Dataset_Documentation/NHIS/2002/. Accessed on August 1, 2009.

17. Giles WH, Croft JB, Keenan NL, Lane MJ, Wheeler FC. The validity of self-reported hypertension and correlates of hypertension awareness among blacks and whites within the stroke belt. Am J Prev Med. 1995; 11:163-169.

18. Vargas CM, Burt VL, Gillum RF, Pamuk ER. Validity of self-reported hypertension in the National Health and Nutrition Examination Survey III, 1988-1991. Prev Med. 1997;26:678-685.

19. Bartlett DL, Ezzati-Rice TM, Stokley S, Zhao Z. Comparison of NIS and NHIS/NIPRCS vaccination coverage estimates. National Immunization Survey. National Health Interview Survey/National Immunization Provider Record Check Study. Am J Prev Med. 2001; 20(4 Suppl):25-27.

20. Yabroff KR, Gordis L. Assessment of a national health interview survey-based method of measuring community socioeconomic status. Ann Epidemiol. 2003;13:721-726.

21. National Health Interview Survey: research for the 1995-2004 redesign. Vital Health Stat 2. 1999;(126):1-119.

22. Design and estimation for the National Health Interview Survey, 1995-2004. Vital Health Stat 2. 2000;(130):1-31.

23. An AB. Performing Logistic Regression on Survey Data with the New SURVEYLOGISTIC Procedure. Paper 258-27. Proceedings of the 27th Annual SAS Users Group International Conference (SUGI 27). Orlando, FL, April 14-17, 2002, 1-9.
24. Breslow NE, Day NE. Statistical methods in cancer research. Volume I. The analysis of case-control studies. IARC Sci Publ. 1980;32:5-338.

25. Sin DD, Man SF. Chronic obstructive pulmonary disease as a risk factor for cardiovascular morbidity and mortality. Proc Am Thorac Soc. 2005;2:8-11.

26. Engstrom G, Hedblad B, Janzon L. Reduced lung function predicts fatality in future cardiac events. A population-based sutdy. $J$ Intern Med. 2006;260:560-567.

27. Jousilahti P, Vartiainen E. Symptoms of chronic bronchitis and the risk of coronary disease. Lancet. 1996;348:567-572.

28. Huiart L, Ernst P, Suissa S. Cardiovascular morbidity and mortality in COPD. Chest. 2005;128:2640-2646.

29. Salisbury AC, Reid KJ, Spertus JA. Impact of chronic obstructive pulmonary disease on post-myocardial infarction outcomes. Am J Cardiol. 2007;99:636-641.

30. Schroeder EB, Welch VL, Couper D, et al. Lung function and incident coronary heart disease: the Atherosclerosis Risk in Communities Study. Am J Epidemiol. 2003;158:1171-1181.

31. Mortensen EM, Copeland LA, Pugh MJ, et al. Impact of statins and ACE inhibitors on mortality after COPD exacerbations. Respir Res. 2009; $10: 45$.

32. Stavem K, Aaser E, Sandvik L, et al. Lung function, smoking and mortality in a 26-year follow-up of healthy middle-aged males. Eur Respir J. 2005;25:618-625.

33. Gan WQ, Man SF, Senthilselvan A, Sin DD. Association between chronic obstructive pulmonary disease and systemic inflammation: a systematic review and meta-analysis. Thorax. 2004;59:574-580.

34. Cohen RI, Marzouk K, Berkoski P, O’Donnell CP, Polotsky VY, Scharf SM. Body composition and resting energy expenditure in clinically stable, non-weight-losing patients with severe emphysema. Chest. 2003;124:1365-1372.

35. Suissa S, Hemmelgarn B, Blais L, Ernst P. Bronchodilators and acute cardiac death. Am J Respir Crit Care Med. 1996;154:1598-1602.

36. Kiely DG, Cargill RI, Grove A, Struthers AD, Lipworth BJ. Abnormal myocardial repolarisation in response to hypoxaemia and fenoterol. Thorax. 1995;50:1062-1066.

37. Au DH, Lemaitre RN, Curtis JR, Smith NL, Psaty BM. The risk of myocardial infarction associated with inhaled beta-adrenoceptor agonists. Am J Respir Crit Care Med. 2000;161:827-830.

38. Suissa S, Assimes T, Ernst P. Inhaled short acting $\beta$ agonist use in COPD and the risk of acute myocardial infarction. Thorax. 2003; 58:43-46

39. Truelsen T, Prescott E, Lange P, Schnohr P, Boysen G. Lung function and risk of fatal and non-fatal stroke. The Copenhagen City Heart Study. Int J Epidemiol. 2001;30(1):145-151.

40. Singh S, Loke YK, Furberg CD. Inhaled anticholinergics and risk of major adverse cardiovascular events in patients with chronic obstructive pulmonary disease: a systematic review and meta-analysis. JAMA. 2008;300(12):1439-1450.

41. Lee TA, Pickard AS, Au DH, Bartle B, Weiss KB. Risk for death associated with medications for recently diagnosed chronic obstructive pulmonary disease. Ann Intern Med. 2008;149(6):380-390.

42. Ogale SS, Lee TA, Au DH, Boudreau DM, Sullivan SD. Cardiovascular Events Associated With Ipratropium Bromide in COPD. Chest. 2009; Apr 10. [Epub ahead of print].

43. Macie C, Wooldrage K, Manfreda J, Anthonisen N. Cardiovascular morbidity and the use of inhaled bronchodilators. Int J Chron Obstruct Pulmon Dis. 2008;3(1):163-169.

44. Rana JS, Mittleman MA, Sheikh J, et al. Chronic obstructive pulmonary disease, asthma, and risk of type 2 diabetes in women. Diabetes Care. 2004;27:2478-2484.

45. Andreas S, Anker SD, Scanlon PD, Somers VK. Neurohumoral activation as a link to systemic manifestations of chronic lung disease. Chest. 2005;128:3618-3624.

46. Stein PK, Nelson P, Rottman JN, et al. Heart rate variability reflects severity of COPD in PiZ alpha1-antitrypsin deficiency. Chest. 1998; 113:327-333. 
47. Newman AB, Naydeck BL, Sutton-Tyrrell K, Feldman A, Edmundowicz D, Kuller LH. Coronary artery calcification in older adults to age 99: prevalence and risk factors. Circulation. 2001;104:2679-2684.

48. Sabit R, Bolton CE, Edwards PH, et al. Arterial stiffness and osteoporosis in chronic obstructive pulmonary disease. Am J Respir Crit Care Med. 2007;175:1259-1265.

49. Schols AM, Fredrix EW, Soeters PB, Westerterp KR, Wouters EF. Resting energy expenditure in patients with chronic obstructive pulmonary disease. Am J Clin Nutr. 1991;54:983-987.

50. Garcia-Aymerich J, Lange P, Benet M, Schnohr P, Antó JM. Regular physical activity modifies smoking-related lung function decline and reduces risk of chronic obstructive pulmonary disease: a populationbased cohort study. Am J Respir Crit Care Med. 2007;175:458-463.

51. Mannino DM. COPD: epidemiology, prevalence, morbidity and mortality, and disease heterogeneity. Chest. 2002;121(5 Suppl): $121 \mathrm{~S}-126 \mathrm{~S}$.

52. Ramsey SD, Sullivan SD. The burden of illness and economic evaluation for COPD. Eur Respir J. 2003;21(Suppl 41):29S-35S.

53. Malarcher AM, Schulman J, Epstein LA, et al. Methodological issues in estimating smoking-attributable mortality in the United States. Am J Epidemiol. 2000;152(6):573-584.

54. Egede LE, Zheng D. Racial/ethnic differences in influenza vaccination coverage in high-risk adults. Am J Public Health. 2003;93(12): 2074-2078.

55. Egede LE. Major depression in individuals with chronic medical disorders: prevalence, correlates and association with health resource utilization, lost productivity and functional disability. Gen Hosp Psychiatry. 2007;29(5):409-416.
56. Pleis JR, Barnes PM. A comparison of respiratory conditions between multiple race adults and their single race counterparts: an analysis based on American Indian/Alaska Native and white adults. Ethn Health 2008;13(5):399-415.

57. Harlow SD, Linet MS. Agreement between questionnaire data and medical records. The evidence for accuracy of recall. Am J Epidemiol. 1989;129(2):233-248

58. Leikauf J, Federman AD. Comparisons of self-reported and chartidentified chronic diseases in inner-city seniors. J Am Geriatr Soc. 2009;57(7):1219-1225.

59. Global Initiative for Chronic Obstructive Lung Disease. [machinereadable data files], 2008. Available from http://www.goldcopd.com. Accessed August 1, 2009.

60. Davies JC, Alton EW. Monitoring respiratory disease severity in cystic fibrosis. Respir Care. 2009;54(5):606-617.

61. Altintas A, Demir T, Ikitimur HD, Yildirim N. Pulmonary function in multiple sclerosis without any respiratory complaints. Clin Neurol Neurosurg. 2007;109(3):242-246.

62. Yeh HC, Punjabi NM, Wang NY, et al. Cross-sectional and prospective study of lung function in adults with type 2 diabetes: the Atherosclerosis Risk in Communities (ARIC) study. Diabetes Care. 2008;31(4): 741-746.

63. Steele RM, Finucane FM, Griffin SJ, Wareham NJ, Ekelund U. Obesity is associated with altered lung function independently of physical activity and fitness. Obesity. 2009;17(3):578-584

64. Moayyeri A, Bingham SA, Luben RN, Wareham NJ, Khaw KT. Respiratory function as a marker of bone health and fracture risk in an older population. J Bone Miner Res. 2009;24(5):956-963.
International Journal of COPD

\section{Publish your work in this journal}

The International Journal of COPD is an international, peer-reviewed journal of therapeutics and pharmacology focusing on concise rapid reporting of clinical studies and reviews in COPD. Special focus is given to the pathophysiological processes underlying the disease, intervention programs, patient focused education, and self management protocols.

\section{Dovepress}

This journal is indexed on PubMed Central, MedLine and CAS. The manuscript management system is completely online and includes a very quick and fair peer-review system, which is all easy to use. Visit http://www.dovepress.com/testimonials.php to read real quotes from published authors. 